\title{
Therapeutic implications of fibroblast growth factor receptor inhibitors in a combination regimen for solid tumors (Review)
}

\author{
HONG LUO ${ }^{1}$, TAO ZHANG $^{1}$, PENG CHENG ${ }^{1}$, DONG LI ${ }^{1}$, OLEKSANDR OGORODNITTCHOUK ${ }^{2}$, \\ CHAIMAA LAHMAMSSI ${ }^{2}$, GE WANG $^{3}$ and MEILING LAN ${ }^{4}$ \\ ${ }^{1}$ Department of Oncology, General Hospital of Western Theater Command, Chengdu, Sichuan 610083, P.R. China; \\ ${ }^{2}$ Institut de Cancérologie Lucien Neuwirth, 42270 Saint Priest en Jarez, France; ${ }^{3}$ Cancer Center, Institute of Surgical Research, \\ Third Affiliated Hospital, Army Medical University (Third Military Medical University), Chongqing 400042; \\ ${ }^{4}$ Cancer Center, The Third Affiliated Hospital of Chongqing Medical University \\ (Jie Er Hospital), Chongqing 401120, P.R. China
}

Received November 22, 2019; Accepted May 22, 2020

DOI: $10.3892 / \mathrm{ol} .2020 .11858$

\begin{abstract}
A number of novel drugs targeting the fibroblast growth factor receptor (FGFR) signaling pathway have been developed, including mostly tyrosine kinase inhibitors, selective inhibitors or monoclonal antibodies. Multiple preclinical and clinical studies have been conducted worldwide to ascertain their effects on diverse solid tumors. Drugs, such as lenvatinib, dovitinib and other non-specific FGFR inhibitors, widely used in clinical practice, have been approved by the Food and Drug Administration for cancer therapy, although the majority of drugs remain in preclinical tests or clinical research. The resistance to a single agent for FGFR inhibition with synthetic lethal action may be overcome by a combination of therapeutic approaches and FGFR inhibitors, which could also enhance the sensitivity to other therapeutics. Therefore, the aim of the present review is to describe the pharmacological characteristics of FGFR inhibitors that may be combined with other therapeutic agents and the preclinical data supporting their combination. Additionally, their clinical implications and the remaining challenges for FGFR inhibitor combination regimens are discussed.
\end{abstract}

\section{Contents}

1. Introduction

2. Combination of FGFR inhibitors with target agents: A sectorial approach

3. Combination with chemotherapeutic agents

Correspondence to: Dr Meiling Lan, Cancer Center, The Third Affiliated Hospital of Chongqing Medical University (Jie Er Hospital), 1 Shuang Hu Zhi Road, Yubei, Chongqing 401120, P.R. China

E-mail: lanmeilingzlk@163.com

Key words: fibroblast growth factor receptor inhibitors, solid tumors, radiotherapy, chemotherapy, targeted therapy, immunotherapy
4. Combination with radiotherapeutics

5. Combination with immune checkpoint inhibitors

6. Conclusions

\section{Introduction}

The fibroblast growth factor receptor (FGFR) signaling pathway is of great importance in a number of fundamental physiological mechanisms, including embryonic development, tissue metabolism homeostasis, endocrine function, angiogenesis and wound repair $(1,2)$. Dysregulation of the FGFR signaling pathway is the principal cause of oncogenesis in numerous types of tumor, causing proliferation, differentiation, apoptosis, migration and resistance to anticancer therapy $(3,4)$. FGFRs, a family of receptor tyrosine kinases (RTKs), have an extracellular ligand-binding domain and an intracellular tyrosine kinase domain; among members of the FGFR family, FGFR1-4 display a highly conserved transmembrane tyrosine kinase domain, whereas FGFR5 does not possess an intracellular kinase domain (5). Activation of FGFRs by the FGF ligand leads to triggering of downstream signaling pathways for cell survival and proliferation, including the PI3K/AKT, STAT and RAS/mitogen-activated protein kinase (MAPK) signaling pathways (6).

Numerous studies have focused on FGFR amplification (7-9), activating mutations $(10,11)$ and oncogenic fusions in solid tumors (12). In oncogenesis, FGFR signaling can also be enhanced by autocrine and paracrine signaling, in addition to angiogenesis and epithelial-mesenchymal transition (13). A number of novel drugs targeting the FGFR signaling pathway, containing multi-targeting tyrosine kinase inhibitors (TKIs), selective inhibitors and monoclonal antibodies, are undergoing preclinical and clinical trials in various FGFR-associated tumors (14). Notably, lenvatinib, dovitinib and other non-specific FGFR inhibitors are currently used as treatments in clinical practice $(15,16)$. However, despite selective inhibitors having been enlisted into the anticancer armamentarium by the Food and Drug Administration, the majority have not concluded preclinical studies or clinical trials (4). 
There is growing evidence that only a fraction of cancer types with FGFR-drivers may respond to FGFR inhibitors (13). In addition, as with the majority of targeted drugs, the development of drug resistance is a critical issue for the efficacy of FGFR inhibition (13). This may suggest that dual suppression of FGFR and other signaling pathways may be a valid approach. Combination therapeutic approaches principally function via two mechanisms: Overcoming the resistance of a single-agent FGFR inhibitor through synthetic lethal action and enhancing the sensitivity of the other therapeutic agent (14). Therefore, combined therapeutic approaches may represent the most promising treatment for tumor therapy, and the aforementioned studies have attempted to identify an FGFR inhibitor-based combination regimen that best improves duration of response and long-term outcomes in solid tumors.

The purpose of the present review is to describe the pharmacological characteristics of FGFR inhibitors that facilitate combination with other therapeutic agents and to identify the preclinical data supporting their combination, in addition to discussing the clinical implications and remaining challenges for FGFR inhibitor combination regimens with radiotherapy, chemotherapy, targeted drugs and immunotherapy.

\section{Combination of FGFR inhibitors with target agents: A sectorial approach}

Lung cancer. Combinations of FGFR inhibitors with targeted agents in different types of cancer are presented in Table I. Concerning mitogen-activated protein kinase kinase (MEK) inhibitors in KRAS-mutant lung adenocarcinoma, their inhibition capability remains robust (17). Trametinib, a MEK inhibitor that targets the MAPK signaling pathway, is particularly effective (17). Indeed, following short hairpin (sh) RNA screening, a compensatory response involving FGFR1 can be promoted by trametinib, leading to negative signaling feedback activity and adaptive drug resistance (17). Therefore, through a combination of trametinib and an FGFR inhibitor, tumor cell death can be enhanced both in vitro and in vivo (17). Notably, this effect was identified in cell lines and xenograft mouse models of KRAS-mutant lung adenocarcinoma and pancreatic carcinoma, but not in KRAS wild-type lung cancer cells or KRAS-mutant colon cancer (17). Therefore, to combat KRAS-mutant lung cancer, combining a MEK inhibitor with an FGFR inhibitor could be regarded as a rational approach (17).

However, based on the epithelial or mesenchymal state of the cancer, MEK inhibitors induce evident activation of RTKs in KRAS-mutant lung cancer (18). In epithelial-like KRAS-mutant cancer cells, MEK inhibitors primarily upregulate Erb-B2 receptor tyrosine kinase 3 (ERBB3) and activate PI3K/AKT and MAPK signaling; by contrast, ERBB3 expression in mesenchymal-like KRAS-mutant lung cancer cells is low (18). Mesenchymal-like cells exhibit higher FGFR1 expression, and with suppression of the Sprouty (SPRY) protein, MEK inhibition relieves inhibition of the FGFR1 signaling pathway (18). Consequently, the combination of FGFR and MEK inhibitors may be more effective in treating mesenchymal-like KRAS-mutant non-small cell lung cancer (NSCLC).

With regards to mTOR inhibitors, in order to identify whether their function as a protein kinase is essential to the intrinsic sensitivity of FGFR1-dependent lung cancer cells to ponatinib (a multi-kinase FGFR-active inhibitor), a previous study has adopted functional genomic screens with a kinome-targeting shRNA library as study objects (19). Synergistic growth can be suppressed in vitro with a combination of an FGFR inhibitor and an mTOR or AKT inhibitor (19). When combining AZD2014 (an mTOR inhibitor) with AZD4547 (an FGFR-specific TKI), distinct attenuation of tumor growth in tumor xenografts generated using FGFR1-dependent lung cancer cells has been observed (19). Additionally, Dai et al (20) identified FGFR2 and $\mathrm{mTOR}$ as critical regulators in a number of wild-type epidermal growth factor receptor (EGFR) NSCLC cell lines in TUSC2-erlotinib combination treatment.

Concerning MET proto-oncogene, receptor tyrosine kinase (MET) inhibitors, previous research has confirmed signaling crosstalk between FGFR and MET (21). Kim et al (21) reported that, in MET-dependent cell lines, FGFR serves an important role in resistance to a MET-targeting antibody. By establishing an acquired resistance model to the FGFR inhibitors AZD4547 and BAY116387 in lung cancer, it has been demonstrated that MET activation is sufficient to bypass the dependency on the FGFR signaling pathway (22). These data indicate that concurrent inhibition of MET and FGFR signaling may be important in FGFR-dependent lung cancer.

With regards to EGFR-specific TKIs, treatment with a single EGFR-TKI appears to represent a logical step in the process towards achieving personalized cancer therapy. However, the long-term benefit is limited by intrinsic and acquired resistance mechanisms. It is well-known that single EGFR-TKI resistance mechanisms include EGFR-T790M 'gate-keeper' mutations and MET amplification (23). Ware et al (24) employed NSCLC cells bearing activating EGFR mutations and rendered them resistant to EGFR-specific TKIs through chronic adaptation in tissue culture. Their data suggest that fibroblast growth factor 2 (FGF2) and FGFR1 expression were increased in the adapted cell lines using combined treatment with gefitinib and AZD4547 and prevented the outgrowth of the drug-resistant clones. The aforementioned findings support FGFR-specific TKIs as potentially valuable additions to existing targeted therapeutic strategies using EGFR-specific TKIs to prevent or delay acquired resistance in EGFR-driven NSCLC.

Concerning GLI family zinc finger (GLI) inhibitors, targeted therapies have substantially improved treatments in lung adenocarcinoma, including EGFR and ALK receptor tyrosine kinase (ALK) inhibitors, and have increased the survival rate of patients (25). It has been demonstrated that NSCLC comprises a subset of stem cell-like cells $(26,27)$. The proportion of FGFR1 amplification is $10-22 \%$ in lung squamous cell carcinoma (LSCC) (28-30). Activation of FGFR1 can enhance the activity of GLI1 in addition to knockdown of GLI2, thereby directly inhibiting the stem cell-like phenotype of FGFR1-amplified cells, suggesting that the FGFR1/GLI2 axis promotes the lung cancer stem cell-like phenotype in LSCC (31). Therefore, a combination of FGFR and GLI inhibitors may be an ideal treatment for FGFR1-amplified LSCC (31).

Head and neck squamous cell carcinoma (HNSCC). FGFR1 inhibitor has displayed its ability to reduce HNSCC development in a preclinical model (32). However, resistance 


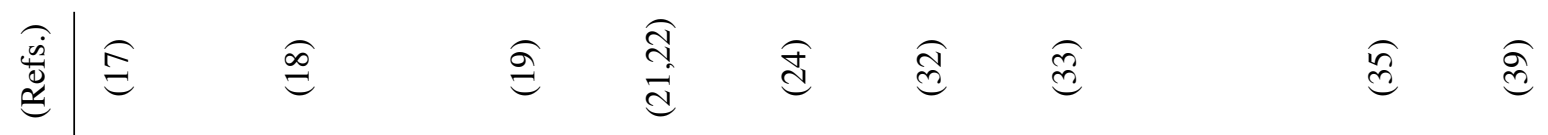

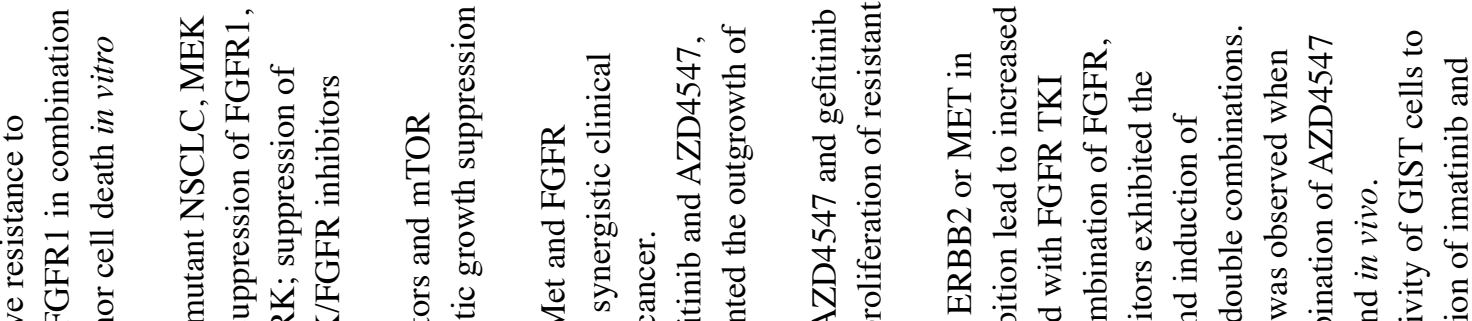

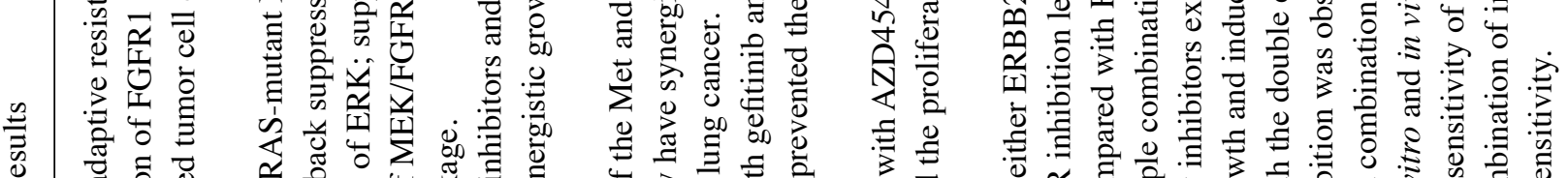

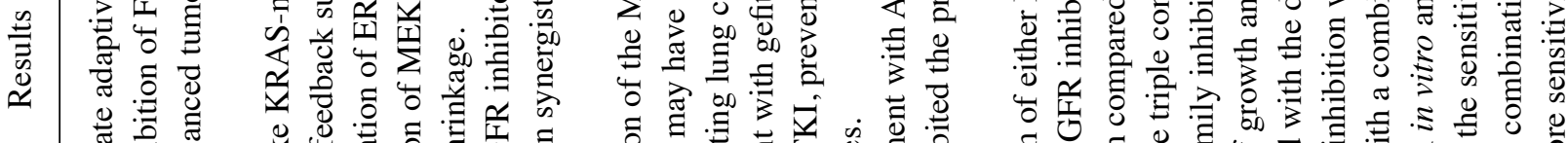

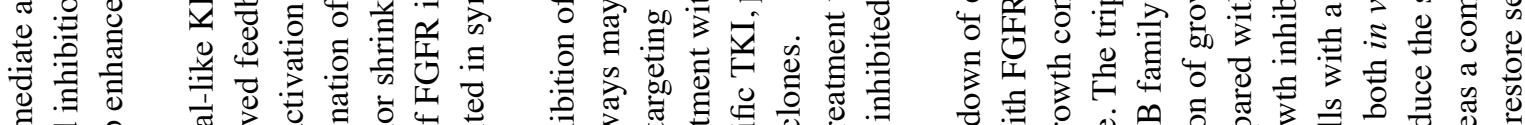

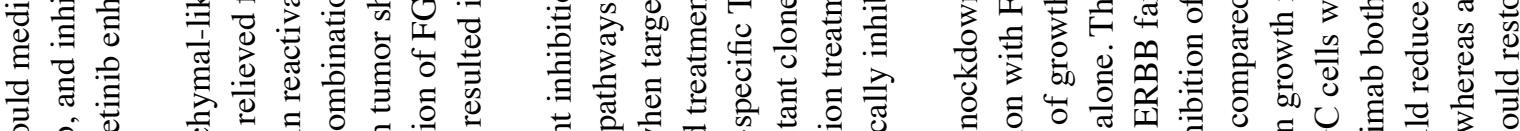

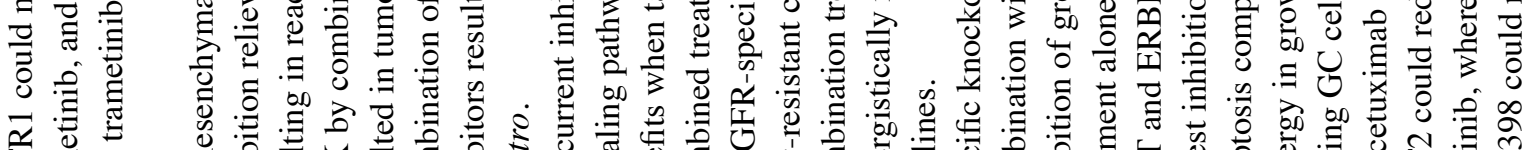

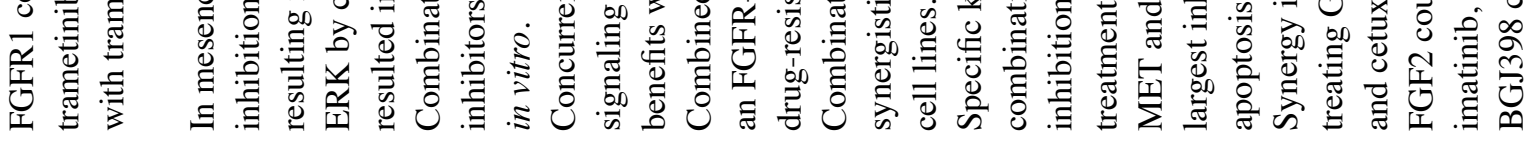

ธี

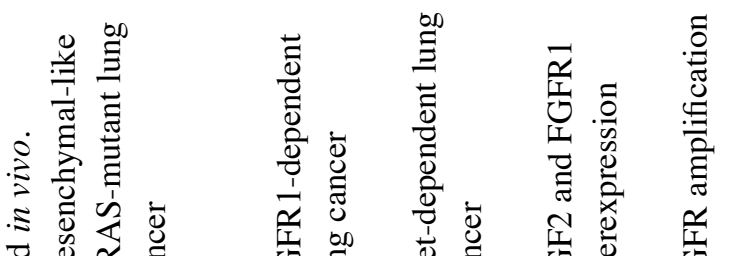

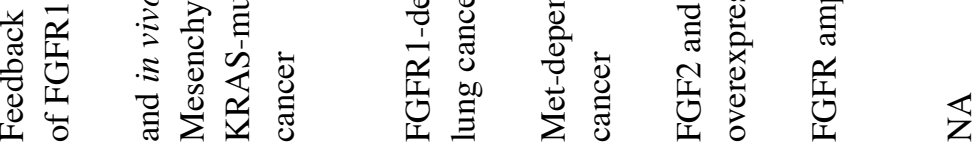

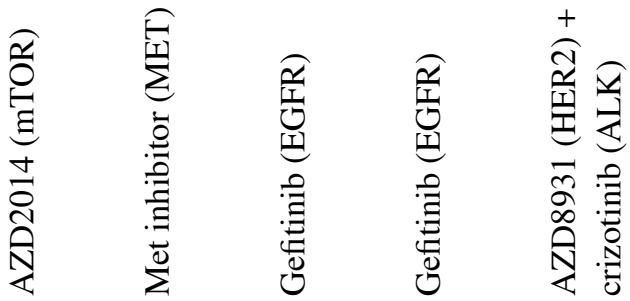

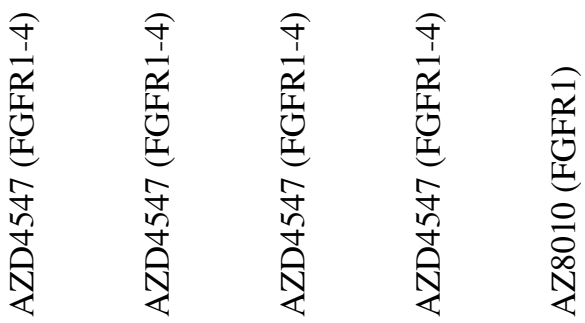

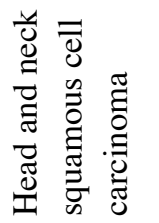

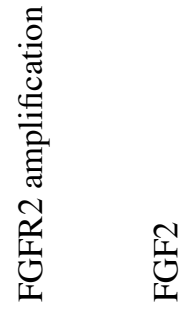

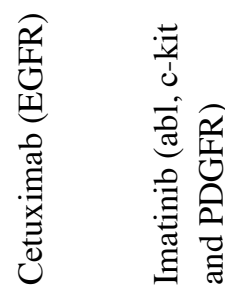

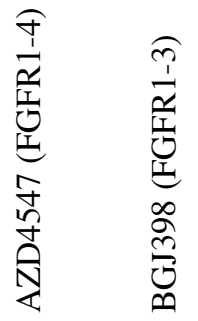

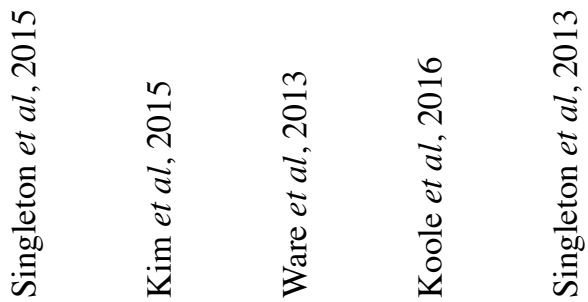

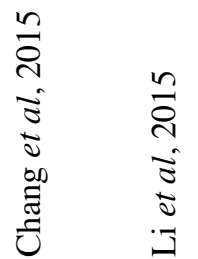




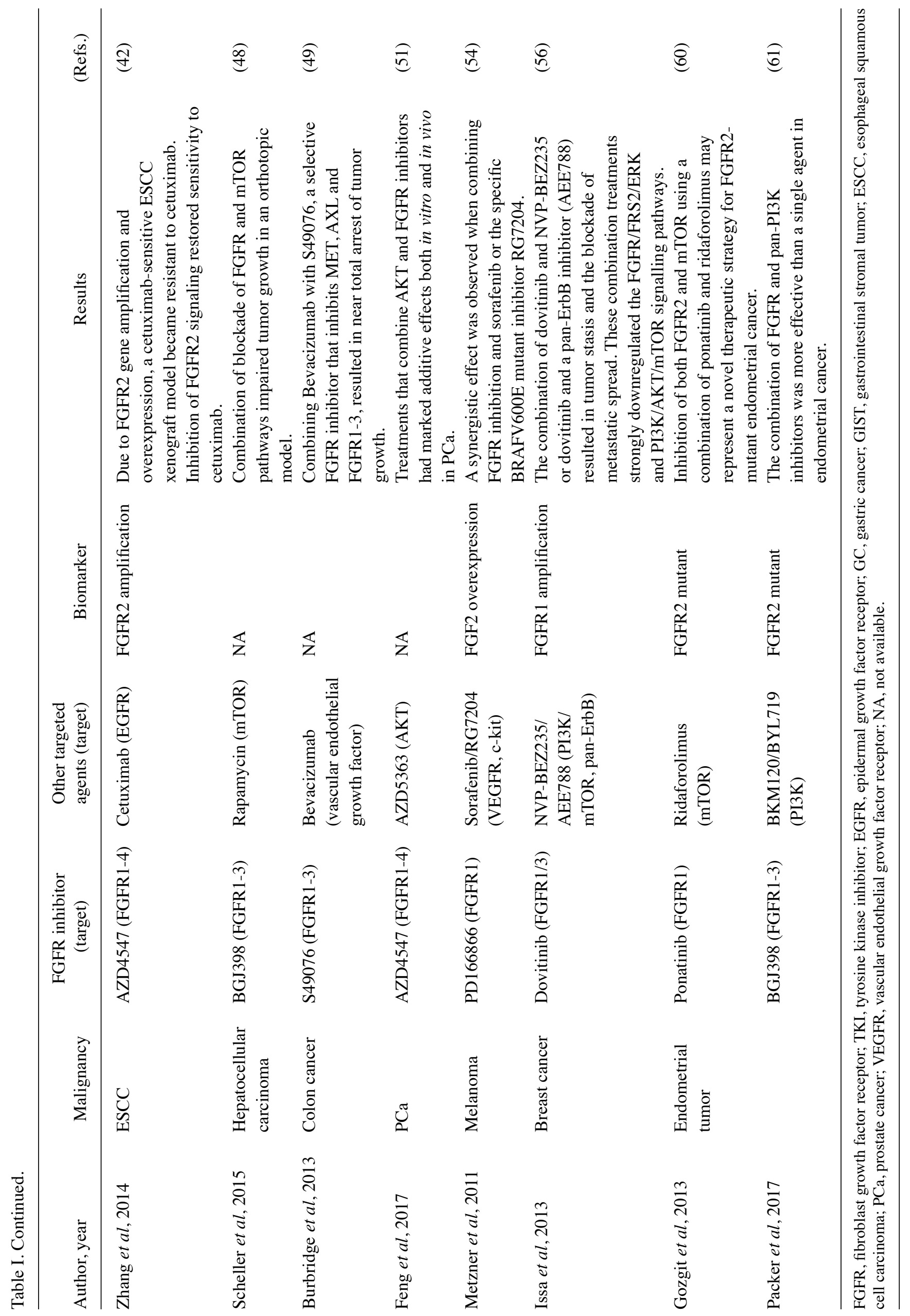


still represents a serious problem (32). In HNSCC cell lines treated with FGFR inhibitors, mTOR serves a crucial role (19). Additionally, FGFR1 protein upregulation may be a prognostic biomarker in human papillomavirus-negative HNSCC, and, due to EGFR signaling, FGFR-amplified cell lines exhibit resistance to AZD4547 (32). The combination of AZD4547 and gefitinib synergistically inhibits the proliferation of resistant cell lines (32). A previous study conducted by the University of Colorado Anschutz Medical Campus included a whole-genome loss-of-function screen to identify genes whose knockdown potentiated the effect of the FGFR inhibitor AZ8010 in three HNSCC cell lines (33). The results indicated that FGFR inhibition did not exert an effect on several alternative receptors, including RTKs, ERBB2 and MET, and that the triple combination of FGFR, MET and ERBB family inhibitors was more effective in inhibition of cell growth and induction of apoptosis compared with double combinations (33).

Gastric cancer $(G C)$ and gastrointestinal stromal tumors (GISTs). FGFR1 and FGFR2 are amplified in numerous types of solid tumor (14). In a translational clinical trial, it was demonstrated that GC with high-level FGFR2 amplification exhibits a high response to the FGFR inhibitor AZD4547 (34). Another study demonstrated that several RTKs, including EGFR, ERBB3 and MET, following activation, contribute to AZD4547 hyposensitivity in FGFR2-amplified GC cells (35). In addition, these resistance-conferring RTKs (EGFR, ERBB3 and MET) were highly expressed in FGFR2-positive patients with GC (35). Furthermore, synergy was observed in growth inhibition when GC cells were treated with AZD4547 and cetuximab, in vitro and in vivo (35). It is well known that for $80 \%$ of patients with GIST, advanced cancer can be controlled by imatinib (36). However, this beneficial effect does not last for long due to the majority of patients developing resistance to imatinib, which can be promoted by signaling cross-talk between KIT proto-oncogene, receptor tyrosine kinase (KIT) and FGFR3 (37). Another study demonstrated that during imatinib therapy in patients undergoing tumor resection, viable tumor cells can be observed in GIST (38). Li et al (39) reported that FGF2 can reduce the sensitivity of GIST cells to imatinib, whereas a combination of imatinib and BGJ398 (infigratinib) can restore this sensitivity. Additionally, the molecular mechanisms underlying the combination treatment have been established, with activation of KIT suppressing FGF signaling through ERK-dependent feedback inhibition, which is partially mediated by SPRY proteins in GIST cells (39).

Esophageal squamous cell carcinoma (ESCC). Acidic FGF and FGFR1 co-expression are associated with poor prognosis in patients with ESCC (40). Using fluorescent in situ hybridization, the frequency and prognosis of FGFR1 amplification in 526 patients with curatively resected ESCC were investigated, identifying high and low amplification of 8.6 and $1.1 \%$, respectively (41). Shorter disease-free survival and overall survival times were observed in the high FGFR1 amplification group compared with the low FGFR1 amplification group (41). By analyzing these data, it can be inferred that FGFR is crucial to ESCC. Zhang et al (42) reported that due to FGFR2 gene amplification and upregulation, a cetuximab-sensitive ESCC xenograft model became resistant to cetuximab, and that inhibition of FGFR2 signaling restored the sensitivity to cetuximab. Additionally, it has been identified that AZD4547 can increase sensitivity to gefitinib in TE10 and EC9706 cell lines; notably, higher expression levels of phospho-FGFR1 were observed in TE10 compared with in EC9706 cells, and in the best case, enhanced sensitivity was achieved (43).

Hepatocellular carcinoma (HCC). At present, surgery is the sole curative treatment option for HCC. However, since patients commonly present at an advanced stage, few qualify for surgical resection or liver transplantation (44). Sorafenib, a multi-TKI, has modest efficacy in patients with HCC (44). Although some studies have demonstrated that MET inhibition can markedly inhibit the growth of MET-positive HCC $(45,46)$, resistance to MET inhibitors remains a major problem. Jo et al (47) have reported that the FGFR signaling pathway is critical for HCC, and that use of AZD4547 may be beneficial for HCC expressing phospho-FGFR and phospho-MET. Scheller et al (48) reported that daily administration $(5 \mathrm{mg} / \mathrm{kg})$ of BGJ398 (infigratinib) causes substantial growth inhibition in vivo; however, in combination with blockade of FGFR and mTOR signaling pathways it impairs tumor growth in an orthotopic model.

Colon carcinoma $(C C)$. Bevacizumab, a monoclonal antibody directed against vascular endothelial growth factor, is widely used clinically, but it can also induce resistance and has a limited duration of efficacy. In HT-29 CC xenografts, treatment with bevacizumab at $10 \mathrm{mg} / \mathrm{kg}$ twice per week led to $71 \%$ inhibition of tumor growth; however, combining bevacizumab with S49076, a selective FGFR inhibitor that inhibits MET, AXL receptor tyrosine kinase and FGFR1-3, results in near total arrest of tumor growth (49).

Prostate cancer (PCa). In a previous study, an FGFR inhibitor has demonstrated that targeting the FGFR signaling pathway can inhibit $\mathrm{PCa}$ progression in vivo (50). It has been recently highlighted that AZD5363 (an AKT inhibitor) partially inhibits AKT kinase activity in addition to increasing FGFR1 signaling (51). Therefore, treatments that combine AKT and FGFR inhibitors have marked additive effects both in vitro and in vivo in $\mathrm{PCa}(51)$.

Human melanoma. Frequent mutations in BRAF and FGF2 upregulation are the principal features of melanoma $(52,53)$. Metzner et al (54) proposed an antitumor strategy in melanoma that restrains FGFR signals using the small-molecule inhibitors SU5402 and PD166866, leading to reduced melanoma cell proliferation and increased apoptosis. This synergistic effect has been observed when combining FGFR inhibition and sorafenib or the specific BRAF ${ }^{\mathrm{V} 600 \mathrm{E}}$ mutant inhibitor RG7204 (vemurafenib) (54).

Gynecological tumors. In $\sim 10 \%$ of breast cancer cases, it has been demonstrated that FGFR1 and FGFR2, which are associated with poor outcomes, become amplified (55). Dovitinib, a selective FGFR inhibitor, inhibits FGFR1-amplified breast cancer xenografts (55). However, blocking a single signaling pathway is often not sufficient to generate tumor regression. 
Additionally, the efficacy of a single therapeutic agent is often short-lived due to the emergence of resistant cancer cells. In breast cancer models, the combination of dovitinib and the PI3K/mTOR inhibitor NVP-BEZ235, or dovitinib and a pan-ErbB inhibitor (AEE788), results in tumor stasis and the blockade of metastatic spread (56). These combination treatments strongly downregulate the FGFR/fibroblast growth factor receptor substrate 2 (FRS2)/ERK and PI3K/AKT/mTOR signaling pathways (56). On the other hand, treatment with an FGFR1 inhibitor induces stroma remodeling, which is of importance for tumor dormancy and recurrence (57). Holdman et al (57) used transgenic mouse models to study the recurrence of FGFR1-driven breast tumors, and their data suggest that the phospho-EGFR signaling pathway is upregulated in recurrent tumors. In addition, the combination of EGFR and FGFR1 inhibitors markedly decreases collagen-enriched stroma formation and substantially delays tumor recurrence (57). There are currently two phase II expansion trials evaluating the efficacy of FGFR inhibitors in combination with fulvestrant in a second-line setting for endocrine resistance in breast cancer (NCT01202591 and NCT01528345). A variety of genetic alterations has been observed in endometrial tumors, including FGFR2 mutations (58). Notably, the PI3K signaling pathway is activated in $>90 \%$ of FGFR2-mutant endometrial cancers (59). Two studies have explored the effects of FGFR inhibitors upstream and downstream of the PI3K signaling pathway, respectively. Gozgit et al (60) confirmed inhibition of both FGFR2 and mTOR when using a combination of ponatinib and ridaforolimus, which may represent a novel therapeutic strategy for FGFR2-mutant endometrial cancer. Another study evaluated the combination of BGJ398 (infigratinib), the pan-PI3K inhibitor BKM120 and the p110 $\alpha$-selective inhibitor BYL719 (alpelisib) in FGFR2-mutant endometrial cancer, suggesting that the combination of FGFR and pan-PI3K inhibitors may be more effective than a single agent in endometrial cancer (61).

\section{Combination with chemotherapeutic agents}

Combinations of FGFR inhibitors with different chemotherapeutic agents are shown in Table II. ARQ 087 is a multi-TKI with activity against FGFR and with a safe profile, and it induces regression of tumors in FGFR-driven models (62). Chilà et al (63) assessed the feasibility of combining ARQ 087 with chemotherapy in FGFR-dysregulated human xenografts, including lung cancer (H1581), endometrial cancer (MFE296) and GC (SNU16) models. In the lung cancer model, ARQ 087 exhibited limited antitumor activity, but, compared with single agents, a higher degree of tumor regression and a longer time to progression were observed using a combination of ARQ $087+$ paclitaxel + carboplatin (63). Similar treatments were used in nude mice bearing SNU16 and MFE296 xenografts. Notably, no toxic deaths were observed and no premature stopping or delay of drug administration were required (63). For endometrial cancer, chemotherapy is the standard treatment; however, the use of chemotherapeutic agents is limited due to toxicity in numerous patients with recurrent or advanced disease (64). Byron et al (65) explored the combination of PD173074 and paclitaxel or doxorubicin with synergistic activity in three FGFR2-mutant cell lines.
FGFR2 mutation status did not alter sensitivity to either chemotherapeutic agent alone, while the combination of PD173074 with paclitaxel or doxorubicin exhibited synergistic activity in the three FGFR2-mutant cell lines evaluated (65). Notably, non-mutant cell lines exhibited resistance to FGFR inhibition alone, but the cytostatic effect of paclitaxel and doxorubicin was enhanced by the addition of PD173074 (65). Furthermore, >90\% of solid tumors harbor a p53 mutation leading to dysregulation of $\mathrm{G}_{2} / \mathrm{M}$ cell cycle checkpoints in unique and predictable ways, in addition to insensitivity to chemotherapy (66). Additionally, in p53-mutant endometrial cancer cells, synthetic lethality can be achieved through a combination of paclitaxel and BIBF1120 (nintedanib), an investigational vascular endothelial growth factor receptor, platelet-derived growth factor receptor and FGFR multi-TKI (66).

Recently, a study evaluated the effect of BGJ398 (infigratinib) in an ovarian cancer cell line (SKOV3ip1) with the help of a 3D sphere culture system (67). Notably, the viability of sphere-cultured SKOV3ip1 cells was decreased by BGJ398 (infigratinib) treatment, but viability of SKOV3ip1 cells in a monolayer culture system was not affected (67). Furthermore, a synergistic inhibitory effect was observed when BGJ398 (infigratinib) was combined with paclitaxel in sphere-cultured SKOV3ip1 cells (67).

Additionally, the combination of PD166866 and cisplatin had a synergistic effect in malignant pleural mesothelioma SPC111, SPC212 and P31 cells; however, in the cisplatin-resistant P31 cell line, PD166866 did not revert cisplatin sensitivity (68). Using PD166866 alone, its inhibitory effect in the cisplatin-resistant derivative was greater than that observed in the parental cell lines (68). Another study demonstrated that co-culture of colorectal cancer cells with tumor-associated fibroblasts (TAF) induces significant FGFR4 upregulation, and that FGFR4 serves crucial roles in TAF-induced epithelial-to-mesenchymal transition in colorectal cancer cell lines (69). Accumulated FGFR4 in the cell membrane phosphorylates $\beta$-catenin, leading to translocation of $\beta$-catenin into the nucleus (69). Furthermore, TAF-derived CCL2 and its downstream transcription factor are prerequisites for TAF-induced FGFR4 upregulation (69).

Upregulation of FGFR4 expression has been demonstrated to be associated with the response to doxorubicin in colon cancer cells (70). A role for FGFR4 as a regulator of signal transduction through the regulation of cellular FADD-like IL-1 $\beta$-converting enzyme-inhibitory protein (c-FLIP; an anti-apoptotic protein) and B-cell lymphoma- 2 with activation of STAT3 has been previously described in colon cancer (71). In addition, Turkington et al described the role of FGFR4 in the resistance to fluorouracil and oxaliplatin chemotherapy (71). Induction of apoptosis was observed in cell line models, whereas silencing of FGFR4 in combination with chemotherapy downregulated c-FLIP expression (71). These data may provide a therapeutic strategy in which FGFR4-selective small-molecule inhibitors are combined with chemotherapy in order to reverse chemoresistance in colon cancer.

\section{Combination with radiotherapeutics}

The effects of FGFR inhibitors in combination with radiotherapy have not been fully explored. Indeed, the effects 
Table II. Combination of FGFR inhibitors with chemotherapeutics.

\begin{tabular}{|c|c|c|c|c|c|}
\hline Author, year & Malignancy & $\begin{array}{c}\text { FGFR inhibitor } \\
\text { (target) }\end{array}$ & Chemotherapeutics & Results & (Refs) \\
\hline Chilà et al, 2017 & $\begin{array}{l}\text { Lung cancer/ } \\
\text { endometrial } \\
\text { cancer/gastric } \\
\text { cancer }\end{array}$ & $\begin{array}{l}\text { ARQ087 } \\
\text { (FGFR1-3) }\end{array}$ & $\begin{array}{l}\text { Paclitaxel + } \\
\text { carboplatin }\end{array}$ & $\begin{array}{l}\text { In a lung cancer model, ARQ } 087 \\
\text { exhibited limited antitumor activity. } \\
\text { However, compared with single } \\
\text { agents, a higher degree of tumor } \\
\text { regression and a longer time to } \\
\text { progression were observed using a } \\
\text { combination of ARQ } 087+\text { paclitaxel } \\
+ \text { carboplatin. }\end{array}$ & $(63)$ \\
\hline Byron et al, 2012 & $\begin{array}{l}\text { Endometrial } \\
\text { cancer }\end{array}$ & $\begin{array}{l}\text { PD173074 } \\
\text { (FGFR1-4) }\end{array}$ & $\begin{array}{l}\text { Paclitaxel/ } \\
\text { doxorubicin }\end{array}$ & $\begin{array}{l}\text { Non-mutant cell lines exhibited } \\
\text { resistance to FGFR inhibition alone, } \\
\text { but the cytostatic effect of paclitaxel } \\
\text { and doxorubicin was enhanced by the } \\
\text { addition of PD173074. }\end{array}$ & $(65)$ \\
\hline Meng et al, 2013 & & $\begin{array}{l}\text { BIBF } 1120 \\
(\text { FGFR } 1 / 2 / 3)\end{array}$ & Paclitaxel & $\begin{array}{l}\text { In p53-mutant endometrial cancer } \\
\text { cells, synthetic lethality could be } \\
\text { achieved through a combination of } \\
\text { paclitaxel and BIBF1120. }\end{array}$ & $(66)$ \\
\hline Cha et al, 2017 & $\begin{array}{l}\text { Ovarian } \\
\text { cancer }\end{array}$ & $\begin{array}{l}\text { BGJ398 } \\
\text { (FGFR1-3) }\end{array}$ & Paclitaxel & $\begin{array}{l}\text { A synergistic inhibitory effect } \\
\text { was observed when BGJ398 was } \\
\text { combined with paclitaxel in sphere- } \\
\text { cultured SKOV3ip1 cells. }\end{array}$ & $(67)$ \\
\hline $\begin{array}{l}\text { Schelch et al, } \\
2014\end{array}$ & $\begin{array}{l}\text { Malignant } \\
\text { pleural } \\
\text { mesothelioma }\end{array}$ & $\begin{array}{l}\text { PD166866 } \\
\text { (FGFR1) }\end{array}$ & Cisplatin & $\begin{array}{l}\text { The combination of PD166866 and } \\
\text { cisplatin had a synergistic effect in } \\
\text { malignant pleural mesothelioma. }\end{array}$ & $(68)$ \\
\hline $\begin{array}{l}\text { Turkington et al, } \\
2014\end{array}$ & Colon cancer & $\begin{array}{l}\text { small interfering } \\
\text { RNA-mediated } \\
\text { silencing } \\
\text { (FGFR4) }\end{array}$ & $\begin{array}{l}\text { Fluorouracil + } \\
\text { oxaliplatin }\end{array}$ & $\begin{array}{l}\text { Induction of apoptosis was observed } \\
\text { in cell line models, whereas silencing } \\
\text { of FGFR } 4 \text { in combination with } \\
\text { chemotherapy downregulated c-FLIP } \\
\text { expression. }\end{array}$ & (71) \\
\hline
\end{tabular}

FGFR, fibroblast growth factor receptor.

of FGFR inhibitors in combination with radiotherapy have only been explored in a few studies (Table III). Verstraete et al (72) evaluated the effects of JNJ-42756493 (a pan-FGFR TKI) with and without radiotherapy in rectal cancer. While irradiation with 5 Gy in NCI-H716 cells (FGFR2 amplification) or $10 \mathrm{~Gy}$ in $\mathrm{CaCo} 2$ cells (with low/undetected FGFR2 protein expression) hindered tumor growth in both cell models, the addition of an FGFR inhibitor did not result in radio-sensitization; however, irradiation with 5 Gy prevented the accelerated growth of NCI-H716 cells following drug withdrawal (72).

Notably, another study reported that FGFR4 can induce radiotherapy resistance in colorectal cancer (CRC) and explored the response to neo-adjuvant radiotherapy in CRC cell line models through silencing or overexpression of FGFR4 (73). It was identified that the FGFR4 staining score was substantially lower in biopsies of responsive rather than of non-responsive mice; similarly, radiation response in cell models was inhibited by FGFR4 overexpression (73). When radiation and PD173074 (an FGFR inhibitor) were used to block FGFR4-dependent signaling, a marked decrease in surviving colony forming cells was observed in small interfering RNA-induced FGFR4 silencing (73). PD173074 was administered $3 \mathrm{~h}$ prior to irradiation and the treatment was continued after irradiation, resulting in a marked decrease in the surviving fraction and the median effective radiation dose (73). Ader et al (74) demonstrated that SSR128129E, a novel small molecule multi-FGFR blocker, clearly increased the radiosensitivity of human glioblastoma cells both in vitro and in vivo, modulating hypoxia inducible factor (HIF)-1 $\alpha$ expression under hypoxia in vitro. The function of PD166866, a multi-FGFR inhibitor, occurs mainly in the following ways: By improving the curative effect of cisplatin and improving the sensitivity of radiotherapy in mesothelioma (68). Based on the available data, FGFR induces radiosensitization, which is associated with attenuation of double-strand break repair by RAD51 recombinase-mediated homologous recombination (73). On the other hand, it also increases radiation-induced mitotic cell death and decreases cell membrane availability of FGFR-1 by increasing the ubiquitylation of the receptor, inhibiting radiation-induced ras homolog family member $\mathrm{B}$ activation and modulating the level of HIF (74). 
Table III. Combination of FGFR inhibitors with radiotherapy.

\begin{tabular}{|c|c|c|c|c|c|}
\hline Author, year & Malignancy & $\begin{array}{c}\text { FGFR inhibitor } \\
\text { (target) }\end{array}$ & Biomarker & Results & (Refs) \\
\hline Verstraete et al, 2015 & Rectal cancer & $\begin{array}{l}\text { JNJ-42756493 } \\
\text { (FGFR1-4) }\end{array}$ & $\begin{array}{l}\text { FGFR2 } \\
\text { amplification }\end{array}$ & $\begin{array}{l}\text { Irradiation with } 5 \text { Gy prevented the } \\
\text { accelerated growth of NCI-H716 } \\
\text { cells following drug withdrawal. }\end{array}$ & (72) \\
\hline Ahmed et al, 2019 & colorectal cancer & $\begin{array}{l}\text { PD173074 } \\
\text { (FGFR1-4) }\end{array}$ & $\begin{array}{l}\text { FGFR } 4 \\
\text { overexpression }\end{array}$ & $\begin{array}{l}\text { PD173074 was applied } 3 \mathrm{~h} \text { before } \\
\text { irradiation and the treatment was } \\
\text { continued after irradiation and } \\
\text { resulted in a marked decrease of the } \\
\text { surviving fraction and the median } \\
\text { effective radiation dose. }\end{array}$ & (73) \\
\hline Ader et al, 2014 & Glioblastoma & SSR-128129E & $\begin{array}{l}\text { FGF-2 } \\
\text { (FGFR1) }\end{array}$ & $\begin{array}{l}\text { SSR128129E, a novel small } \\
\text { molecule multi-FGFR } \\
\text { blocker, markedly increased } \\
\text { the radiosensitivity of human } \\
\text { glioblastoma cells in vitro and } \\
\text { in vivo. }\end{array}$ & (74) \\
\hline Schelch et al, 2014 & Mesothelioma & $\begin{array}{l}\text { PD166866 } \\
\text { (FGFR } 1)\end{array}$ & $\begin{array}{l}\text { FGFR1 over- } \\
\text { expression }\end{array}$ & $\begin{array}{l}\text { PD166866, a multi-FGFR inhibitor, } \\
\text { could improve the curative effect } \\
\text { of cisplatin and the sensitivity to } \\
\text { radiotherapy in mesothelioma. }\end{array}$ & $(68)$ \\
\hline
\end{tabular}

FGFR, fibroblast growth factor receptor.

\section{Combination with immune checkpoint inhibitors}

In recent years, multiple studies have focused on the development of immunotherapy, which has been exponentially administered for a number of tumor types, such as melanoma (75), lung cancer (76) and urothelial cancer (77). This leads to a dramatic change in treatment focus, from a metastatic to an adjuvant setting (78,79). Recently, Yost et al (80) have explored the mechanism of immune checkpoint inhibitors, indicating that their use may have been limited by pre-existing tumor-specific T cells and a distinct repertoire of T-cell clones that may generate an immune response against checkpoint inhibitors. This has great value and significance in clinical treatment and detection of efficacy.

Nevertheless, only a small number of patients have enjoyed the clinical benefits of targeted or immune therapies due to the emergence of resistance. Driver pathway segments in NSCLC (such as EGFR, ALK and KRAS) have been investigated to establish the finite benefits of immunotherapy, suggesting that these oncogenes provide an escape from immuno-surveillance for the tumors by changes in the tumor microenvironment (81). This concept focuses on the ability of targeted therapies to induce immunogenic cell death, by which tumor antigen presentation to $\mathrm{T}$ cells can be enhanced (82). Therefore, the immune activating potential of checkpoint inhibitors can improve functionality of T cells (82). Additionally, FGFR3 signaling pathways were activated in non-T-cell-inflamed tumors (83), indicating that inhibition of the FGFR signaling pathway may be adopted as an effective method of eliciting T-cell infiltration. Clinical trials that are underway or beginning soon will assess the combination of FGFR inhibitors with pembrolizumab for the treatment of locally advanced or metastatic urothelial cell carcinoma (NCT03123055; Table IV).

One study indicated that programmed death-ligand 1 (PD-L1) and FGFR2 were frequently overexpressed and that FGFR2 expression was strongly associated with lymph node metastasis, clinical stage and poor survival in patients with CRC (84). Recently, Palakurthi et al (85) explored the potential combination of erdafitinib, an FGFR inhibitor under clinical development, with programmed cell death protein 1 (PD-1) blockade in an autochthonous FGFR2K660N/p53-mutant lung cancer mouse model. Although no survival benefit was observed with either erdafitinib or anti-PD-1 monotherapy treatment, their combination contributed to the expansion of T-cell clones and immunological changes in the tumor microenvironment, leading to enhanced antitumor immunity and survival (85). Furthermore, it was demonstrated that the antitumor effect of this combination was dependent on erdafitinib-induced tumor cell killing, de novo priming and enhancement of antitumor T-cell response via PD-1 blockade (85). The rationale for the clinical evaluation of erdafitinib in combination with PD-1/PD-L1 blocking agents in patients with FGFR-altered tumors who have poor T-cell infiltration and are normally refractory to PD-1 blockade, is explained further in the aforementioned study.

\section{Conclusions}

FGFR inhibitors may serve as a combination partner with a promising future for a variety of newly-developed regimens for curing a number of indications in solid tumors. Based on 
Table IV. Clinical trials with FGFR inhibitor-based combination regimens in solid tumors.

\begin{tabular}{|c|c|c|c|c|}
\hline Malignancy & Study title and result & Phase & Status & Trial no. \\
\hline $\begin{array}{l}\text { Urothelial } \\
\text { carcinoma }\end{array}$ & $\begin{array}{l}\text { A multi-center, open-label phase Ib/II study of a novel FGFR3 } \\
\text { inhibitor (b-701) combined with pembrolizumab in subjects with } \\
\text { locally advanced or metastatic urothelial carcinoma who have } \\
\text { progressed following platinum-based chemotherapy. } \\
\text { Result: incomplete trial. }\end{array}$ & Phase Ib/II & Terminated & NCT03123055 \\
\hline $\begin{array}{l}\text { Pancreatic } \\
\text { cancer }\end{array}$ & $\begin{array}{l}\text { Pan-FGFR kinase inhibitor BGJ398 and combination } \\
\text { chemotherapy in treating patients with untreated metastatic } \\
\text { pancreatic cancer. } \\
\text { Result: incomplete trial. }\end{array}$ & Phase Ib/II & Withdrawn & NCT02575508 \\
\hline $\begin{array}{l}\text { Non-small } \\
\text { cell lung } \\
\text { cancer }\end{array}$ & $\begin{array}{l}\text { Docetaxel with or without FGFR inhibitor AZD } 4547 \text { in treating } \\
\text { patients with recurrent non-small cell lung cancer. } \\
\text { Result: A total of } 3 \text { dose levels of AZD } 4547 \text { were planned ( } 40 \text {, } \\
60 \text { and } 80 \mathrm{mg}) \text { in combination with a standard dose of docetaxel } \\
\left(75 \mathrm{mg} / \mathrm{m}^{2}\right) . \text { Serious adverse events included hypotension, } \\
\text { decreased lymphocyte count, neutrophil count and white blood } \\
\text { cells compared with their normal values. }\end{array}$ & Phase I/II & Completed & NCT01824901 \\
\hline $\begin{array}{l}\text { Colorectal } \\
\text { cancer }\end{array}$ & $\begin{array}{l}\text { Irinotecan plus brivanib in metastatic colorectal cancer enriched } \\
\text { for elevated levels of plasma FGF. } \\
\text { Result: incomplete trial. }\end{array}$ & Phase II & Terminated & NCT01367275 \\
\hline $\begin{array}{l}\text { Breast } \\
\text { cancer }\end{array}$ & $\begin{array}{l}\text { Safety and efficacy of AZD4547 in combination with fulvestrant } \\
\text { vs. fulvestrant alone in } \mathrm{ER}^{+} \text {breast cancer patients (GLOW). } \\
\text { Result: Safety and tolerability in terms of number of patients } \\
\text { with adverse events (serious and non-serious). Among the } \\
89 \text { patients enrolled, } 80 \text { were not eligible and } 9 \text { received the } \\
\text { treatment. Serious adverse events in the group of AZD } 4547+ \\
\text { fulvestrant represented } 40 \% \text { (inflammation and gait disturbance), } \\
\text { while in the placebo }+ \text { fulvestrant group } 25 \% \text { (dizziness). There } \\
\text { were no other (not including serious) adverse events. }\end{array}$ & Phase IIa & Completed & NCT01202591 \\
\hline & $\begin{array}{l}\text { Trial evaluating dovitinib combined with fulvestrant, in } \\
\text { postmenopausal patients with HER2 }{ }^{-} \text {and } \mathrm{HR}^{+} \text {breast cancer. } \\
\text { Result: The median PFS (95\% CI) was } 5.5(3.8-14.0) \text { months } \\
\text { vs. 5.5 (3.5-10.7) months in the dovitinib vs. placebo arms, } \\
\text { respectively. For the FGF pathway-amplified subgroup, the } \\
\text { median PFS (95\% CI) was } 10.9(3.5-16.5) \text { months vs. } 5.5 \\
(3.5-16.4) \text { months in the dovitinib vs. placebo arms, respectively. } \\
\text { Frequently reported adverse events in the dovitinib (diarrhea, } \\
\text { nausea, vomiting, asthenia and headache) and placebo (diarrhea, } \\
\text { fatigue, nausea and asthenia) arms were mostly low grade. }\end{array}$ & Phase II & Terminated & NCT01528345 \\
\hline
\end{tabular}

FGFR, fibroblast growth factor receptor; HER2, human epidermal growth factor receptor 2; HR, hormone receptor; ER, estrogen receptor; PFS, progression-free survival.

the aforementioned accumulated knowledge, the molecular basis for combination is fourfold. Firstly, changes that occur in the target itself prevent interaction with other drugs. Secondly, FGFR signaling allows cancer cells to escape from the antitumor effects of other target agents. Thirdly, inhibition is bypassed by tumor cells through crosstalk and feedback loops of FGFR signaling pathways. Fourthly, FGFR inhibition may drive T-cell infiltration, which in turn has an effect in cooperation with anti-PD-1, and therefore promotes antitumor immunity. However, to the best of our knowledge, only a few clinical trials have been conducted to assess the combination of FGFR inhibitors with other therapeutics in patients with cancer
(Table IV). Despite the toxic effects of combined therapy, which may be an important limiting factor in implementing these combinations in clinical practice, the results of these trials remain unknown.

In conclusion, developing novel treatment regimens that target multiple aberrant signaling pathways has distinct rationality. These treatments may offer potent and irreversible signaling inhibition in all FGFR-driven solid tumors. Research on FGFR inhibitor-based combinations indicates that knowledge of molecular tumor pathogenesis is essential for the development of novel therapeutic strategies that can improve cancer outcomes in the foreseeable future. 


\section{Acknowledgements}

The authors would like to thank Dr Benoite Mery (Institut de Cancérologie Lucien Neuwirth, Saint Priest en Jarez, France) for proofreading the English language of the manuscript.

\section{Funding}

The present study was supported by the National Natural Science Foundation of China (grant no. 81572959).

\section{Availability of data and materials}

Not applicable.

\section{Authors' contributions}

HL and ML wrote the manuscript draft. ML and GW contributed to the preparation of the manuscript. CL, OO, TZ, PC and DL revised the manuscript. All authors read and approved the final manuscript.

\section{Ethics approval and consent to participate}

Not applicable.

\section{Patient consent for publication}

Not applicable.

\section{Competing interests}

The authors declare that they have no competing interests.

\section{References}

1. Neilson KM and Friesel R: Ligand-independent activation of fibroblast growth factor receptors by point mutations in the extracellular, transmembrane, and kinase domains. J Biol Chem 271: 25049-25057, 1996

2. Itoh N and Ornitz DM: Fibroblast growth factors: From molecular evolution to roles in development, metabolism and disease. J Biochem 149: 121-130, 2011.

3. Funato N, Moriyama K, Shimokawa H and Kuroda T: Basic fibroblast growth factor induces apoptosis in myofibroblastic cells isolated from rat palatal mucosa. Biochem Biophys Res Commun 240: 21-26, 1997

4. Dienstmann R, Rodon J, Prat A, Perez-Garcia J, Adamo B, Felip E, Cortes J, Iafrate AJ, Nuciforo P and Tabernero J: Genomic aberrations in the FGFR pathway: Opportunities for targeted therapies in solid tumors. Ann Oncol 25: 552-563, 2014

5. Touat M, Ileana E, Postel-Vinay S, André F and Soria JC: Targeting FGFR signaling in cancer. Clin Cancer Res 21: 2684-2694, 2015.

6. Gallo LH, Nelson KN, Meyer AN and Donoghue DJ: Functions of fibroblast growth factor receptors in cancer defined by novel translocations and mutations. Cytokine Growth Factor Rev 26 425-449, 2015

7. Weiss J, Sos ML, Seidel D, Peifer M, Zander T, Heuckmann JM, Ullrich RT, Menon R, Maier S, Soltermann A, et al: Frequent and focal FGFR1 amplification associates with therapeutically tractable FGFR1 dependency in squamous cell lung cancer. Sci Transl Med 2: 62ra93, 2010.

8. Lee HJ, Seo AN, Park SY, Kim JY, Park JY, Yu JH, Ahn JH and Gong G: Low prognostic implication of fibroblast growth factor family activation in triple-negative breast cancer subsets. Ann Surg Oncol 21: 1561-1568, 2014.
9. Campbell J, Ryan CJ, Brough R, Bajrami I, Pemberton HN, Chong IY, Costa-Cabral S, Frankum J, Gulati A, Holme H, et al: Large-scale profiling of kinase dependencies in cancer cell lines. Cell Rep 14: 2490-2501, 2016.

10. Helsten T, Elkin S, Arthur E, Tomson BN, Carter J and Kurzrock R: The FGFR landscape in cancer: Analysis of 4,853 tumors by next-generation sequencing. Clin Cancer Res 22: 259-267, 2016.

11. Greenman C1, Stephens P, Smith R, Dalgliesh GL, Hunter C, Bignell G, Davies H, Teague J, Butler A, Stevens C, et al: Patterns of somatic mutation in human cancer genomes. Nature 446: 153-158, 2007.

12. Costa R, Carneiro BA, Taxter T, Tavora FA, Kalyan A, Pai SA, Chae YK and Giles FJ: FGFR3-TACC3 fusion in solid tumors: Mini review. Oncotarget 7: 55924-55938, 2016.

13. Babina IS and Turner NC: Advances and challenges in targeting FGFR signalling in cancer. Nat Rev Cancer 17: 318-332, 2017.

14. Chae YK, Ranganath K, Hammerman PS, Vaklavas C, Mohindra N, Kalyan A, Matsangou M, Costa R, Carneiro B, Villaflor VM, et al: Inhibition of the fibroblast growth factor receptor (FGFR) pathway: The current landscape and barriers to clinical application. Oncotarget 8: 16052-16074, 2017.

15. Suyama K and Iwase H: Lenvatinib: A promising molecular targeted agent for multiple cancers. Cancer Control 25: $1073274818789361,2018$.

16. Yoon JC, Hye SK, Se HP, Kim BS, Kyoung HK, Hyo JL, Hong SS, Shin DY, Lee HY, Kim HG, et al: Phase II study of dovitinib in patients with castration-resistant prostate cancer (KCSG-GU11-05). Cancer Res Treat 50: 1252-1259, 2018.

17. Manchado E, Weissmueller S, Morris JP IV, Chen CC, Wullenkord R, Lujambio A, de Stanchina E, Poirier JT, Gainor JF, Corcoran RB, et al: A combinatorial strategy for treating KRAS-mutant lung cancer. Nature 534: 647-651, 2016.

18. Kitai H, Ebi H, Tomida S, Floros KV, Kotani H, Adachi Y, Oizumi S, Nishimura M, Faber AC and Yano S: Epithelial-to-mesenchymal transition defines feedback activation of receptor tyrosine kinase signaling induced by MEK inhibition in KRAS-mutant lung cancer. Cancer Discov 6: 754-769, 2016.

19. Singleton KR, Hinz TK, Kleczko EK, Marek LA, Kwak J, Harp T, Kim J, Tan AC and Heasley LE: Kinome RNAi screens reveal synergistic targeting of MTOR and FGFR1 pathways for treatment of lung cancer and HNSCC. Cancer Res 75: 4398-4406, 2015.

20. Dai B, Yan S, Lara-Guerra H, Kawashima H, Sakai R, Jayachandran G, Majidi M, Mehran R, Wang J, Bekele BN, et al: Exogenous restoration of TUSC 2 expression induces responsiveness to erlotinib in wildtype epidermal growth factor receptor (EGFR) lung cancer cells through context specific pathways resulting in enhanced therapeutic efficacy. PLoS One 10: e0123967, 2015.

21. Kim B, Wang S, Lee JM, Jeong Y, Ahn T, Son DS, Park HW, Yoo HS, Song YJ, Lee E, et al: Synthetic lethal screening reveals FGFR as one of the combinatorial targets to overcome resistance to Met-targeted therapy. Oncogene 34: 1083-1093, 2015.

22. Kim SM, Kim H, Yun MR, Kang HN, Pyo KH, Park HJ, Lee JM, Choi HM, Ellinghaus P, Ocker M, et al: Activation of the Met kinase confers acquired drug resistance in FGFR-targeted lung cancer therapy. Oncogenesis 5: e241, 2016.

23. Shang-Gin W and Jin-Yuan S: Management of acquired resistance to EGFR TKI-targeted therapy in advanced non-small cell lung cancer. Mol Cancer 17: 38, 2018.

24. Ware KE, Hinz TK, Kleczko E, Singleton KR, Marek LA, Helfrich BA, Cummings CT, Graham DK, Astling D, Tan AC and Heasley LE: A mechanism of resistance to gefitinib mediated by cellular reprogramming and the acquisition of an FGF2-FGFR1 autocrine growth loop. Oncogenesis 2: e39, 2013.

25. Greulich $\mathrm{H}$ : The genomics of lung adenocarcinoma: Opportunities for targeted therapies. Genes Cancer 1: 1200-1210, 2010.

26. Eramo A, Lotti F, Sette G, Pilozzi E, Biffoni M, Di Virgilio A, Conticello C, Ruco L, Peschle C and De Maria R: Identification and expansion of the tumorigenic lung cancer stem cell population. Cell Death Differ 15: 504-514, 2008.

27. Justilien V, Regala RP, Tseng IC, Walsh MP, Batra J, Radisky ES, Murray NR and Fields AP: Matrix metalloproteinase-10 is required for lung cancer stem cell maintenance, tumor initiation and metastatic potential. PLoS One 7: e35040, 2012.

28. Kim HR, Kim DJ, Kang DR, Lee JG, Lim SM, Lee CY, Rha SY, Bae MK, Lee YJ, Kim SH, et al: Fibroblast growth factor receptor 1 gene amplification is associated with poor survival and cigarette smoking dosage in patients with resected squamous cell lung cancer. J Clin Oncol 31: 731-737, 2013. 
29. Seo AN, Jin Y, Lee HJ, Sun PL, Kim H, Jheon S, Kim K, Lee CT and Chung JH, FGFR1 amplification is associated with poor prognosis and smoking in non-small-cell lung cancer. Virchows Arch 465: 547-558, 2014

30. Tran TN, Selinger CI, Kohonen-Corish MRJ, McCaughan BC, Kennedy CW, O'Toole SA and Cooper WA: Fibroblast growth factor receptor 1 (FGFR1) copy number is an independent prognostic factor in non-small cell lung cancer. Lung Cancer 81: 462-467, 2013

31. Ji W, Yu Y, Li Z, Wang G, Li F, Xia W and Lu S: FGFR1 promotes the stem cell-like phenotype of FGFR1-amplified non-small cell lung cancer cells through the Hedgehog pathway. Oncotarget 7 : 15118-15134, 2016

32. Koole K, Brunen D, van Kempen PM, Noorlag R, de Bree R, Lieftink C, van Es RJ, Bernards R and Willems SM: FGFR1 is a potential prognostic biomarker and therapeutic target in head and neck squamous cell carcinoma. Clin Cancer Res 22: 3884-3893, 2016.

33. Singleton KR, Kim J, Hinz TK, Marek LA, Casás-Selves M, Hatheway C, Tan AC, DeGregori J and Heasley LE: A receptor tyrosine kinase network composed of fibroblast growth factor receptors, epidermal growth factor receptor, v-erb-b2 erythroblastic leukemia viral oncogene homolog 2 , and hepatocyte growth factor receptor drives growth and survival of head and neck squamous carcinoma cell lines. Mol Pharmacol 83: 882-893, 2013.

34. Pearson A, Smyth E, Babina IS, Herrera-Abreu MT, Tarazona N, Peckitt C, Kilgour E, Smith NR, Geh C, Rooney C, et al: High-level clonal FGFR amplification and response to FGFR inhibition in a translational clinical trial. Cancer Discov 6 : 838-851, 2016

35. Chang J, Wang S, Zhang Z, Liu X, Wu Z, Geng R, Ge X, Dai C, Liu R, Zhang Q, et al: Multiple receptor tyrosine kinase activation attenuates therapeutic efficacy of the fibroblast growth factor receptor 2 inhibitor AZD4547 in FGFR2 amplified gastric cancer. Oncotarget 6: 2009-2022, 2015.

36. Schlemmer M, Bauer S, Schütte R, Hartmann J, Bokemeyer C, Hosius C and Reichardt P: Activity and side effects of imatinib in patients with gastrointestinal stromal tumors: Data from a German multicenter trial. Eur J Med Res 16: 206-212, 2011.

37. Javidi-Sharifi N, Traer E, Martinez J, Gupta A, Taguchi T, Dunlap J, Heinrich MC, Corless CL, Rubin BP, Druker BJ and Tyner JW: Crosstalk between KIT and FGFR3 promotes gastrointestinal stromal tumor cell growth and drug resistance. Cancer Res 75: 880-891, 2015.

38. Bauer S, Hartmann JT, de Wit M, Lang H, Grabellus F, Antoch G Niebel W, Erhard J, Ebeling P,Zeth M, et al: Resection of residual disease in patients with metastatic gastrointestinal stroma tumors responding to treatment with imatinib. Int J Cancer 117: $316-325,2005$

39. Li F, Huynh H, Li X, Ruddy DA, Wang Y, Ong R, Chow P, Qiu S, Tam A, Rakiec DP, et al: FGFR-mediated reactivation of MAPK signaling attenuates antitumor effects of imatinib in gastrointestinal stromal tumors. Cancer Discov 5: 438-541, 2015.

40. Sugiura K, Ozawa S, Kitagawa Y, Ueda M and Kitajima M: Co-expression of aFGF and FGFR-1 is predictive of a poor prognosis in patients with esophageal squamous cell carcinoma Oncol Rep 17: 557-564, 2007.

41. Kim HS, Lee SE, Bae YS, Kim DJ, Lee CG, Hur J, Chung H, Park JC, Jung DH, Shin SK, et al: Fibroblast growth factor receptor 1 gene amplification is associated with poor survival in patients with resected esophageal squamous cell carcinoma. Oncotarget 6: 2562-2572, 2015.

42. Zhang Y, Pan T, Zhong X and Cheng C: Resistance to cetuximab in EGFR-overexpressing esophageal squamous cell carcinoma xenografts due to FGFR2 amplification and overexpression. J Pharmacol Sci 126: 77-83, 2014

43. Luo H, Quan J, Xiao H, Luo J, Zhang Q, Pi G, Ye Y, He R Liu Y, Su X, Zhao L and Wang G: FGFR inhibitor AZD4547 can enhance sensitivity of esophageal squamous cell carcinoma cells with epithelial-mesenchymal transition to gefitinib. Oncol Rep 39: 2270-2278, 2018.

44. Pinter M and Peck-Radosavljevic M: Review article: Systemic treatment of hepatocellular carcinoma. Aliment Pharmacol Ther 48: 598-609, 2018.

45. Kaposi-Novak P, Lee JS, Gòmez-Quiroz L, Coulouarn C, Factor VM and Thorgeirsson SS: Met-regulated expression signature defines a subset of human hepatocellular carcinomas with poor prognosis and aggressive phenotype. J Clin Invest 116: 1582-1595, 2006.
46. You H, Ding W, Dang H, Jiang Y and Rountree CB: c-Met represents a potential therapeutic target for personalized treatment in hepatocellular carcinoma. Hepatology 54: 879-889, 2011.

47. Jo JC, Choi EK, Shin JS, Moon JH, Hong SW, Lee HR, Kim SM, Jung SA, Lee DH, Jung SH, et al: Targeting FGFR pathway in human hepatocellular carcinoma: Expressing pFGFR and pMET for antitumor activity. Mol Cancer Ther 14: 2613-2622, 2015.

48. Scheller T, Hellerbrand C, Moser C, Schmidt K, Kroemer A, Brunner SM, Schlitt HJ, Geissler EK and Lang SA: mTOR inhibition improves fibroblast growth factor receptor targeting in hepatocellular carcinoma. Br J Cancer 112: 841-580, 2015.

49. Burbridge MF, Bossard CJ, Saunier C, Fejes I, Bruno A, Léonce S, Ferry G, Da Violante G, Bouzom F, Cattan V, et al: S49076 is a novel kinase inhibitor of MET, AXL, and FGFR with strong preclinical activity alone and in association with bevacizumab. Mol Cancer Ther 12: 1749-1762, 2013.

50. Feng S, Shao L, Yu W, Gavine P and Ittmann M: Targeting fibroblast growth factor receptor signaling inhibits prostate cancer progression. Clin Cancer Res 18: 3880-3888, 2012.

51. Feng S, Shao L, Castro P, Coleman I, Nelson PS, Smith PD, Davies BR and Ittmann M: Combination treatment of prostate cancer with FGF receptor and AKT kinase inhibitors. Oncotarget 8: 6179-6192, 2017.

52. Ibrahim N and Haluska FG: Molecular pathogenesis of cutaneous melanocytic neoplasms. Annu Rev Pathol 4: 551-579, 2009.

53. Beenken A and Mohammadi M: The FGF family: Biology, pathophysiology and therapy. Nat Rev Drug Discov 8: 235-253, 2009.

54. Metzner T, Bedeir A, Held G, Peter-Vörösmarty B, Ghassemi S, Heinzle C, Spiegl-Kreinecker S, Marian B, Holzmann K, Grasl-Kraupp B, et al: Fibroblast growth factor receptors as therapeutic targets in human melanoma: Synergism with BRAF inhibition. J Invest Dermatol 131: 2087-2095, 2011.

55. André F, Bachelot T, Campone M, Dalenc F, Perez-Garcia JM, Hurvitz SA, Turner N, Rugo H, Smith JW, Deudon S, et al: Targeting FGFR with dovitinib (TKI258): Preclinical and clinical data in breast cancer. Clin Cancer Res 19: 3693-3702, 2013.

56. Issa A, Gill JW, Heideman MR, Sahin O, Wiemann S, Dey JH and Hynes NE: Combinatorial targeting of FGF and ErbB receptors blocks growth and metastatic spread of breast cancer models. Breast Cancer Res 15: R8, 2013.

57. Holdman XB, Welte T, Rajapakshe K, Pond A, Coarfa C, Mo Q, Huang S, Hilsenbeck SG, Edwards DP, Zhang X and Rosen JM: Upregulation of EGFR signaling is correlated with tumor stroma remodeling and tumor recurrence in FGFR1-driven breast cancer. Breast Cancer Res 17: 141, 2015.

58. McConechy MK, Ding J, Cheang MC, Wiegand K, Senz J, Tone A, Yang W, Prentice L, Tse K, Zeng T, et al: Use of mutation profiles to refine the classification of endometrial carcinomas. J Pathol 228: 20-30, 2012.

59. Cancer Genome Atlas Research Network, Kandoth C, Schultz N, Cherniack AD, Akbani R, Liu Y, Shen H, Robertson AG, Pashtan I, Shen R, et al: Integrated genomic characterization of endometrial carcinoma. Nature 497: 67-73, 2013.

60. Gozgit JM, Squillace RM, Wongchenko MJ, Miller D, Wardwell S, Mohemmad Q, Narasimhan NI, Wang F, Clackson T and Rivera VM: Combined targeting of FGFR2 and mTOR by ponatinib and ridaforolimus results in synergistic antitumor activity in FGFR2 mutant endometrial cancer models. Cancer Chemother Pharmacol 71: 1315-1323, 2013.

61. Packer LM, Geng X, Bonazzi VF, Ju RJ, Mahon CE, Cummings MC, Stephenson SA and Pollock PM: PI3K inhibitors synergize with FGFR inhibitors to enhance antitumor responses in FGFR2mutant endometrial cancers. Mol Cancer Ther 16: 637-648, 2017.

62. Hall TG, Yu Y, Eathiraj S, Wang Y, Savage RE, Lapierre JM, Schwartz B and Abbadessa G: Preclinical activity of ARQ 087 a novel inhibitor targeting FGFR dysregulation. PLoS One 11: e0162594, 2016.

63. Chilà R, Hall GT, Abbadessa G, Broggini M and Damia G: Multi-chemotherapeutic schedules containing the pan-FGFR inhibitor ARQ 087 are safe and show antitumor activity in different xenograft models. Transl Oncol 10: 153-157, 2017.

64. Bestvina CM and Fleming GF: Chemotherapy for endometrial cancer in adjuvant and advanced disease settings. Oncologist 21 : $1250-1259,2016$

65. Byron SA, Loch DC and Pollock PM: Fibroblast growth factor receptor inhibition synergizes with paclitaxel and doxorubicin in endometrial cancer cells. Int J Gynecol Cancer 22: 1517-1526, 2012. 
66. Meng X, Dizon DS, Yang S, Wang X, Zhu D, Thiel KW and Leslie KK: Strategies for molecularly enhanced chemotherapy to achieve synthetic lethality in endometrial tumors with mutant p53. Obstet Gynecol Int 2013: 828165, 2013.

67. Cha HJ, Choi JH, Park IC, Kim CH, An SK, Kim TJ and Lee JH: Selective FGFR inhibitor BGJ398 inhibits phosphorylation of AKT and STAT3 and induces cytotoxicity in sphere-cultured ovarian cancer cells. Int J Oncol, Mar 15, 2017 (Epub ahead of print).

68. Schelch K, Hoda MA, Klikovits T, Münzker J, Ghanim B, Wagner C, Garay T, Laszlo V, Setinek U, Dome B, et al: Fibroblast growth factor receptor inhibition is active against mesothelioma and synergizes with radio- and chemotherapy. Am J Respir Crit Care Med 190: 763-772, 2014.

69. Liu R, Li J, Xie K, Zhang T, Lei Y, Chen Y, Zhang L, Huang K, Wang K, Wu H, et al: FGFR4 promotes stroma-induced epithelial-to-mesenchymal transition in colorectal cancer. Cancer Res 73: 5926-5935, 2013.

70. Roidl A, Berger HJ, Kumar S, Bange J, Knyazev P and Ullrich A Resistance to chemotherapy is associated with fibroblast growth factor receptor 4 up-regulation. Clin Cancer Res 15: 2058-2066, 2009.

71. Turkington RC, Longley DB, Allen WL, Stevenson L, McLaughlin K, Dunne PD, Blayney JK, Salto-Tellez M, Van Schaeybroeck S and Johnston PG: Fibroblast growth factor receptor 4 (FGFR4): A targetable regulator of drug resistance in colorectal cancer. Cell Death Dis 5: e1046, 2014.

72. Verstraete M, Debucquoy A, Gonnissen A, Dok R, Isebaert S Devos E, McBride W and Haustermans K: In vitro and in vivo evaluation of the radiosensitizing effect of a selective FGFR inhibitor (JNJ-42756493) for rectal cancer. BMC Cancer 15: 946, 2015.

73. Ahmed MA, Selzer E, Dörr W, Jomrich G, Harpain F, Silberhumer GR, Müllauer L, Holzmann K, Grasl-Kraupp B, Grusch M, et al: Correction: Fibroblast growth factor receptor 4 induced resistance to radiation therapy in colorectal cancer. Oncotarget 10: 5385-5386, 2019.

74. Ader I, Delmas C, Skuli N, Bonnet J, Schaeffer P, Bono F, Cohen-Jonathan-Moyal E and Toulas C: Preclinical evidence that SSR128129E-a novel small-molecule multi-fibroblast growth factor receptor blocker-radiosensitises human glioblastoma. Eur J Cancer 50: 2351-2359, 2014.

75. Karlsson AK and Saleh SN: Checkpoint inhibitors for malignant melanoma: A systematic review and meta-analysis. Clin Cosmet Investig Dermatol 10: 325-339, 2017.

76. Giroux Leprieur E, Dumenil C, Julie C, Giraud V, Dumoulin J, Labrune $\mathrm{S}$ and Chinet T: Immunotherapy revolutionises non-small-cell lung cancer therapy: Results, perspectives and new challenges. Eur J Cancer 78: 16-23, 2017.
77. Sharma P, Retz M, Siefker-Radtke A, Baron A, Necchi A, Bedke J, Plimack ER, Vaena D, Grimm MO, Bracarda S, et al: Nivolumab in metastatic urothelial carcinoma after platinum therapy (CheckMate 275): A multicentre, single-arm, phase 2 trial. Lancet Oncol 18: 312-322, 2017.

78. Weber J, Mandala M, Del Vecchio M, Gogas HJ, Arance AM, Cowey CL, Dalle S, Schenker M, Chiarion-Sileni V, Marquez-Rodas I, et al: Adjuvant nivolumab versus ipilimumab in resected stage III or IV melanoma. N Engl J Med 377: 1824-1835, 2017.

79. Antonia SJ, Villegas A, Daniel D, Vicente D, Murakami S, Hui R, Yokoi T, Chiappori A, Lee KH, de Wit M, et al: Durvalumab after chemoradiotherapy in stage III non-small-cell lung cancer. N Engl J Med 377: 1919-1929, 2017.

80. Yost KE, Satpathy AT, Wells DK, Qi Y, Wang C, Kageyama R, McNamara KL, Granja JM, Sarin KY, Brown RA, et al: Clonal replacement of tumor-specific T cells following PD-1 blockade. Nat Med 25: 1251-1259, 2019.

81. Liu X and Cho WC: Precision medicine in immune checkpoint blockade therapy for non-small cell lung cancer. Clin Transl Med 6: 7, 2017.

82. Kroemer G, Galluzzi L, Kepp O and Zitvogel L: Immunogenic cell death in cancer therapy. Annu Rev Immunol 31: 51-72, 2013.

83. Sweis RF, Spranger S, Bao R, Paner GP, Stadler WM, Steinberg G and Gajewski TF: Molecular drivers of the Non-T-cell-inflamed tumor microenvironment in urothelial bladder cancer. Cancer Immunol Res 4: 563-568, 2016.

84. Li P, Huang T, Zou Q, Liu D, Wang Y, Tan X, Wei Y, Qiu H: FGFR2 promotes expression of PD-L1 in colorectal cancer via the JAK/STAT3 signaling pathway. J Immunol 202: 3065-3075, 2019.

85. Palakurthi S, Kuraguchi M, Zacharek SJ, Zudaire E, Huang W, Bonal DM, Liu J, Dhaneshwar A, DePeaux K, Gowaski MR, et al: The combined effect of FGFR inhibition and PD-1 blockade promotes tumor-intrinsic induction of antitumor immunity. Cancer Immunol Res 7: 1457-1471, 2019. 